
Turkey

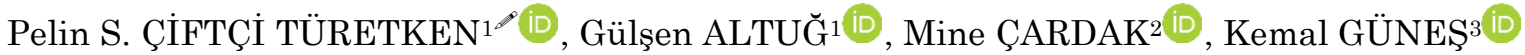 \\ ${ }^{1}$ Istanbul University, Faculty of Aquatic Sciences, Department of Marine Biology, Istanbul, ${ }^{2}$ Canakkale Onsekiz Mart University, School of \\ Applied Sciences, Department of Fisheries Technology, Canakkale, ${ }^{3}$ TÜBİTAK Marmara Research Center, Environment and Cleaner \\ Production Institute, Gebze, Kocaeli \\ $\square:$ pciftci@istanbul.edu.tr
}

\begin{abstract}
In this study, the analyses were carried out to determine oildegradation capacity and oil-resistance levels of bacteria isolated from water surface $(0-30 \mathrm{~cm})$ of nine stations of the Sapanca Lake from September of 2008 to May of 2010. Twenty-seven bacteria species belonging three classes and six families total of eighty-five wild bacteria were identified and screened against crude oil with respect to Minimum Inhibitory Concentration (MIC). Bacterial isolates showing resistance against crude oil were chosen for Emulsification Index $\left(\mathrm{E}_{24}\right)$ test. Isolates displaying higher $\mathrm{E}_{24}$ values were selected for further degradation tests regarding $\mathrm{pH}$ and oil thickness values in experimental setups. Fifty bacterial strains of eighty-five isolates were recorded to be resistant against oil hydrocarbon. Positive reactions percentages of the isolates against crude oil were detected in variable ranges between $25 \%$ and $100 \%$. The results of the emulsification index test for crude oil indicated that the isolates of S49-Stenotrophomonas maltophila, S50-Aeromonas hydrophila, S59E. coli1, S38-Aeromonas hydrophila and S43-Enterobacter cloaceae have higher emulsification percentages. The results of the degradation test showed that isolate of S59-E. coli1 has higher degradation ability than all isolates tested. The bacteria screened against crude oil were detected to be sensitive against crude oil during the first year of the study. Presence of petroleum-resistant bacteria in subsequent tests was associated with the unexpected oil spill occurred in the Sapanca Lake at the time. Detected crude oil resistant bacteria isolates were stocked for a possible use in upcoming bioremediation related studies.
\end{abstract}

\title{
Sapanca Gölü’nden İzole Edilen Bakteri Suşlarının Petrol Hidrokarbonlarını Parçalama Yetenekleri
}

\section{ÖZET}

Bu çalı̧̧mada, Eylül 2008 ile Mayıs 2010 tarihleri arasında Sapanca Gölü’nde belirlenen dokuz istasyonda yüzey sularından $(0-30 \mathrm{~cm})$ izole edilen bakterilerin petrol parçalama kapasiteleri ve direnç düzeylerini belirlemek amacıyla analizler yapılmıştır. Üç sınıf yedi familyaya ait yirmi yedi bakteri türünden oluşan toplam seksen beş doğal bakteri izolatı tanımlanmış ve bu izolatların hepsi Minimum İnhibitör Konsantrasyon (MİK) açısından ham petrole karşı taranmıştır. Emülsifikasyon indeksi $\left(\mathrm{E}_{24}\right)$ testi için ham petrole karşı direnç gösteren bakteri izolatları seçilmiştir. $\mathrm{E}_{24}$ testlerinde yüksek değerler gösteren izolatlar ileri parçalama testlerinde $\mathrm{pH}$ ve petrol katman kalınlığı değerleri kaydedilmek üzere seçilmiştir. Seksen beş izolattan elli tanesi petrol hidrokarbonuna karşı dirençli olarak kaydedilmiştir. Ham petrole karşı pozitif reaksiyon gösteren izolatların yüzdeleri \%25 ile \%100 arasında değişiklik göstermiştir. S49-Stenotrophomonas maltophila, S50-Aeromonas hydrophila, S59E. coli1, S38-Aeromonas hydrophila and S43-Enterobacter cloaceae suşları en yüksek Emülsifikasyon İndeksi yüzdeleri gösteren izolatlar

\section{DOI:10.18016/ ksudobil.344593}

\section{Article History}

Received : 20.10.2017

Accepted : 26.02.2018

Keywords
Crude oil,
wild bacterial isolates,
minimum inhibitory concentration,
Sapanca Lake

\section{Research Article}

\section{Makale Tarihçesi}

Geliş Tarihi : 20.10.2017

Kabul tarihi : 26.02.2018

\author{
Anahtar Kelimeler \\ Ham petrol, \\ doğal bakteri izolatları, \\ minimum inhibisyon konsantrasyonu, \\ Sapanca Gölü
}

\section{Araștırma Makalesi}


olarak kaydedilmiştir. Parçalanma testinin sonuçları, S59-E coli1 izolatının test edilen tüm izolatlardan daha yüksek parçalama kabiliyetine sahip olduğunu göstermiştir. Çalışmanın ilk yılında yapılan ham petrole karşı dirençlilik testlerinde taranan bakterilerin tümünün duyarlı olduğu kaydedilmiştir. Daha sonraki testlerde petrole karşı direnç gösteren bakterilerin tespit edilmesi aynı dönemde Sapanca Gölü’nde meydana gelen beklenmedik petrol sızıntısı ile ilişkilendirilmiştir. Ham petrole dirençli izolatlar, aday bakteriler olarak belirlenmiş ve ileride olası biyoremediasyon çalışmalarında kullanılmak amacıyla stoklanmıştır.

To Cite: Çiftçi Türetken PS, Altuğ G, Çardak M, Güneş K 2018. Oil Hydrocarbon Degradation Capability of Bacterial Strains Isolated from the Sapanca Lake, Turkey. KSÜ Tarim ve Doğa Derg 21(4):535-544,2018. DOI:10.18016/ksudobil.344593

\section{INTRODUCTION}

The biogeochemical importance of bacteria in freshwater ecosystems was first recognized in 1940s, since this early recognition of the critical role of bacteria in regenerating and mobilizing nutrients in freshwater food webs, it has become clear that aquatic bacteria drive transformations and the cycling of most biologically active elements in these ecosystems (Cole, 1988; Cotner, 2002; Newton et al., 2011).

The fate of spilled oil in the aquatic environments depends on a number of factors such as weathering, evaporation, oxidation, biodegradation and emulsification. Oil pollutants in aquatic ecosystems are biodegraded primarily by bacteria, yeast, and fungi. Understanding the degradation capability of bacteria and selecting of the most suitable oil degrading bacteria are important for bioremediation process (Atlas, 1995; Çiftçi and Altuğ, 2010; Das and Chandran, 2011; Marchand et al. 2017). The possible uses of bacteria to obtain more efficiency for degradation of petroleum have become an important topic for bioremediation studies (Le-Petit and Barthelemy, 1968; Ezikpe et al., 2009).

Bacteria can develop tolerance and resistance against some compounds such as oil hydrocarbons, heavy metals and antibiotics, depending on environmental conditions in natural aquatic media. Due to the fact that bacteria play a crucial role in the fate of pollutants, biodegradation of petroleum hydrocarbons in aquatic environments by microorganisms is important (Farrington, 1980; Okoh, 2006).

Lake ecosystems are more sheltered water mass than marine ecosystems. For instance, in Lake Eric (USA), the highest levels of PAHs were found in urbanized harbors in cities (DeBruyn et al., 2009). PAH contamination in lake sediment is widespread. The lakes were located in urbanized watersheds. The study concluded that rapid urbanization in Turkey contributed to this trend. Indeed, heavy industrialization and increased populations in the last decade contributed to the sediment contamination and threatened water supply for nearby areas. Also marine ecosystems have more intense petroleum transporting activities. However, the Sapanca Lake has different character due to the fact that NATO pipeline with respect to potential oil pollution risks.

The Sapanca Lake is one of the major drinking water resources of the Northwestern Turkey. The basin is surrounded by motorways (TEM, Trans-European Motorways) and a railway connecting Asia to Europe (Tanık et al., 1998). Additionally, the NATO pipeline is located to the south of the Sapanca Lake. Accordingly, the Sapanca Lake is under the potential threat of possible oil pollution.

It was documented that Sapanca Lake is under the influence of chemical and biological pollution due to agricultural and industrial activities (Akçaalan et al., 2014; Akkoyunlu and Akiner, 2012; Morkoç 2008; Duman et al., 2007a; 2007b; Anon 1984; 1998). However, there is no data related to oil hydrocarbon and resistant bacteria or biotechnological potential of the bacterial isolates in the region.

In this study, the bacteria isolated from the Sapanca Lake were investigated regarding the minimum inhibitory concentration of crude oil, capability of producing biosurfactants and $\mathrm{pH}$ variables with an aim to detect oil degradation capability and biotechnological potential of the isolates.

\section{MATERIALS and METHODS}

\section{Study Area}

The water samples were taken from water surface (0$30 \mathrm{~cm}$ ) in the nine stations from the Sapanca Lake. The samples collected monthly from September of 2008 to May of 2010. The sampling stations are shown in Figure 1.

The surface water samples were taken to the sterile bottles under aseptic conditions and transported daily with cold chain (APHA, 2000). The samples were analyzed at the Aquatic Microbial Ecology Laboratory of Faculty of Aquatic Sciences of Istanbul University. 


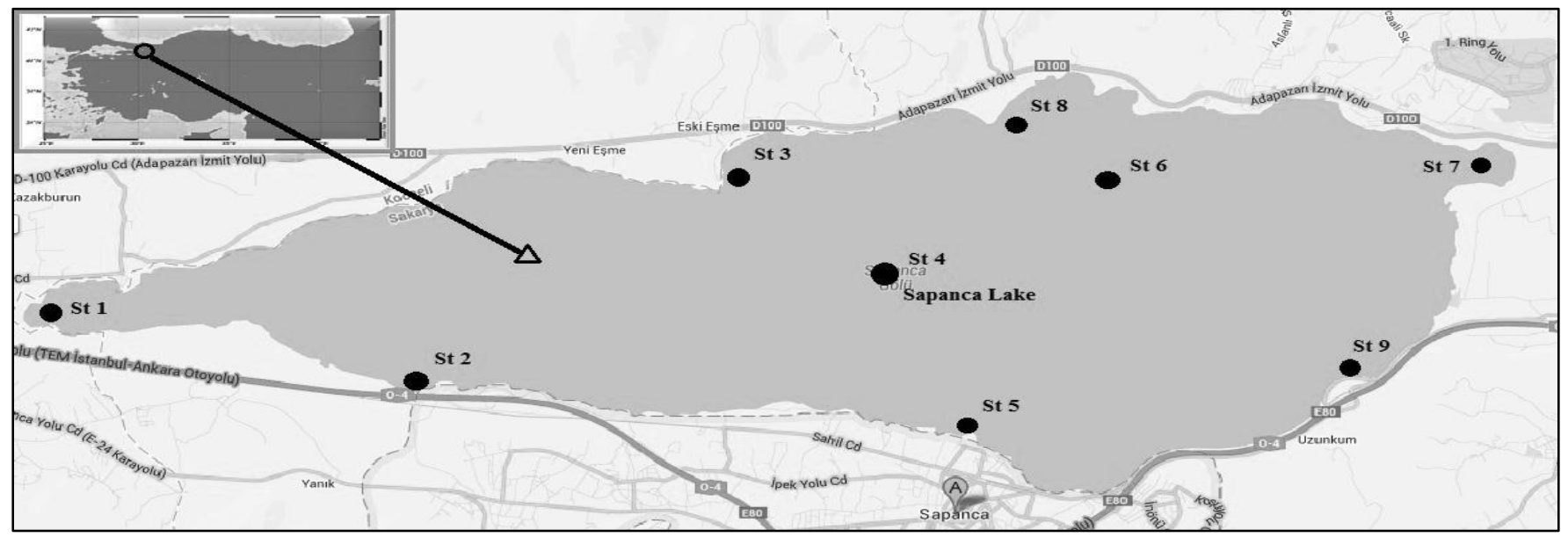

Figure 1. Sampling stations. St 1: Masukiye Stream, St 2: Yanık Stream, St 3: Eşme Stream, St 4: Midpoint of the Lake, St 5: Mahmudiye Stream, St 6: Off the Adasu Water Pump System, St 7: Çark Stream, St 8: Adasu Water Pump System, St 9: Sarp Stream

\section{Bacterial Identification Analyses}

The samples were enriched by Nutrient Broth initially and spread to Pseudomonas agar, TCBS agar, Endo agar, SS agar and Cetrimide agar and were incubated 24 hours at $37 \pm 0.1^{\circ} \mathrm{C}$. Following incubation, different colonies were picked and were recorded according to the colony type, shape and color, and then selected colonies were sub-cultured. The pure isolates were identified using API 20E (Bioméreux). API $20 \mathrm{E}$ is a standardized biochemical identification system for Gram negative rods (Holmes et al., 1978).

\section{Micro Dilution Analyses}

The bacterial suspension cultures, incubated overnight in a mineral salt medium (MSM), were diluted to $3 \times 10^{8}$ cfu/ml by using McFarland No1 standard solution. A volume of $50 \mu \mathrm{l}$ of bacterial suspension and $50 \mu \mathrm{l}$ of MSM (except control cell) was then added into 96 well micro-titer plates. Crude oil was added to 12 unit micro-wells in decreasing amounts ranging from 100 $\mu \mathrm{g} / \mathrm{ml}$ to $0.09 \mu \mathrm{g} / \mathrm{ml}$. The first micro-well (without MSM and containing only crude oil and bacteria) was used to detect bacteria that could survive in media containing crude oil as the only carbon source. The last micro-well without crude oil (bacterial suspension and MSM) was used as a positive growth control (Table 1). After incubation at $37{ }^{\circ} \mathrm{C}$ for $18 \mathrm{~h}$, the petroleum concentration of the well without turbidity was accepted as the minimum inhibitory concentration (MIC) (ANON, 1997).

Table 1. The ratios ( $\mu \mathrm{l})$ of crude oil, MSM and bacterial suspension cultures used for micro-dilution assay

\begin{tabular}{lllllllllllll}
\hline Micro-wells & 1 & 2 & 3 & 4 & 5 & 6 & 7 & 8 & 9 & 10 & 11 & 12 \\
\hline Crude oil $(\mu \mathrm{l})$ & 100 & 50 & 25 & 12.5 & 6.25 & 3.12 & 1.56 & 0.78 & 0.39 & 0.19 & 0.09 & $*$ \\
MSM $(\mu \mathrm{l})$ & $* *$ & 50 & 50 & 50 & 50 & 50 & 50 & 50 & 50 & 50 & 50 & 50 \\
Bacterial suspension $(\mu \mathrm{l})$ & 50 & 50 & 50 & 50 & 50 & 50 & 50 & 50 & 50 & 50 & 50 & 50 \\
\hline
\end{tabular}

*micro-well without crude oil $\quad$ ** micro-well without MSM

\section{Emulsification Index Analyses $\left(\mathrm{E}_{24}\right)$}

For determination of the Emulsification Index of the isolates, $2 \mathrm{ml}$ of a crude oil were added into each $2 \mathrm{ml}$ bacterial culture and the samples were incubated at room temperature for $24 \mathrm{~h}$ after a thorough mix using a vortex for $2 \mathrm{~min}$. The $\mathrm{E}_{24}$ index was determined as the ratio of the height of the emulsified layer $(\mathrm{mm})$ to the total liquid column ( $\mathrm{mm}$ ) (Tabatabaee et al., 2005; Sarubbo, 2006).

\section{Bacterial Biodegradation Capability Analyses}

For degradation tests, minor adjustments were made for each bacterial sample by taking MIC values into consideration. A total of $100 \mathrm{ml} \mathrm{MSM}, 25 \mathrm{ml}$ crude oil and $25 \mathrm{ml}$ bacterial suspension (McFarland No:1 standard solution: $3 \mathrm{x} 10^{8} \mathrm{cfu} / \mathrm{ml}$ ) were added to the sterile flasks. The selected bacterial strains were incubated in batch cultures of $250-\mathrm{ml}$ flasks containing $100 \mathrm{ml}$ of MSM supplemented with $25 \mathrm{ml}$ crude oil as the sole carbon source. Following the addition of a 25 $\mathrm{ml}$ bacterial suspension (McFarland No:1 standard solution: $3 \mathrm{x} 10^{8} \mathrm{cfu} / \mathrm{ml}$ ) to the flasks, the samples were incubated for 30 days at $25^{\circ} \mathrm{C}$ on a shaker (150 rpm) (Rahman et al., 2002). The individual strains were used for degradation studies. The changes of $\mathrm{pH}$ values and oil layers' thickness in the test flasks were recorded at 72 hours' intervals.

\section{RESULTS and DISCUSSION}

The numbers of the isolated bacteria according to the sampling stations were presented on the Table 2 . 
Eighty-five bacterial strains were isolated from the samples taken from the surface water of Sapanca Lake. In this study twenty-seven bacteria species belonging to three classes $(81.5 \%$ Gammaproteobacteria, $14.8 \%$ Bacilli and $3.7 \%$ Flavobacteria) were identified (data not shown; Altug et al., 2018, submitted).

The MIC values of the bacterial isolates were shown on Table 3.

The strains showing resistance against crude oil by MIC tests results were applied to the $\mathrm{E}_{24}$ tests.
The results of $\mathrm{E}_{24}$ tests were shown in Figure 2.

The highest $\mathrm{E}_{24}$ value was determined to be $60 \%$ for S49- $A$. hydrophila and S50- $A$. Hydrophila. Additionally, S59-E. coli1, S38-A. hydrophila and S43$E$. cloaceae sustained the $\mathrm{E}_{24}$ values of $54.73 \%, 50.26 \%$ and $50.06 \%$, respectively.

The thickness of the oil layers and $\mathrm{pH}$ values in the test flasks were recorded at 72 hours' intervals for 30 days. The results of oil layer thickness and $\mathrm{pH}$ values were shown in the Figure 3, 4 and Table 4.

Table 2. Distribution of the isolates according to the sampling stations

\begin{tabular}{|c|c|c|}
\hline Stations & Sampling Locations & $\begin{array}{l}\text { Number of the } \\
\text { Isolates }\end{array}$ \\
\hline St 1 & Masukiye Stream & 9 \\
\hline St 2 & Yanık Stream & 9 \\
\hline St 3 & Eşme Stream & 9 \\
\hline St 4 & Midpoint of the Lake & 9 \\
\hline St 5 & Mahmudiye Stream & 13 \\
\hline St 6 & Off the Adasu Water Pump System & 9 \\
\hline St 7 & Çark Stream & 9 \\
\hline St 8 & Adasu Water Pump System & 9 \\
\hline \multirow[t]{2}{*}{ St 9} & Sarp Stream & 9 \\
\hline & Total Number of the Isolates & 85 \\
\hline
\end{tabular}

Table 3. The bacterial strains that showed MIC values equal or more than $25 \mu$ l against the crude oil.

\begin{tabular}{|c|c|c|c|c|c|c|c|c|c|c|c|c|}
\hline \multirow[b]{2}{*}{ Isolates } & \multicolumn{12}{|c|}{ Crude oil $\mu \mathrm{l}$} \\
\hline & 100 & 50 & 25 & 12.5 & 6.25 & 3.12 & 1.56 & 0.78 & 0.39 & 0.19 & 0.09 & 0 \\
\hline S1 & - & - & - & - & - & - & - & - & - & - & - & - \\
\hline S2 & - & - & - & - & - & - & - & - & - & - & - & - \\
\hline S3 & - & - & - & - & - & - & - & - & - & - & - & - \\
\hline $\mathrm{S} 4$ & - & - & - & - & - & - & - & - & - & - & - & - \\
\hline S5 & - & - & - & - & - & - & - & - & - & - & - & - \\
\hline S6 & - & - & - & - & - & - & - & - & - & - & - & - \\
\hline S7 & - & - & - & - & - & - & - & - & - & - & - & - \\
\hline S8 & - & - & - & - & - & - & - & - & - & - & - & - \\
\hline S9 & - & - & - & - & - & - & - & - & - & - & - & - \\
\hline S10 & - & - & - & - & - & - & - & - & - & - & - & - \\
\hline S11 & - & - & - & - & - & - & - & - & - & - & - & - \\
\hline S12 & - & - & - & - & - & - & - & - & - & - & - & - \\
\hline S13 & - & - & - & - & - & - & - & - & - & - & - & - \\
\hline S14 & - & - & - & - & - & - & - & - & - & - & - & - \\
\hline S15 & - & - & - & - & - & - & - & - & - & - & - & - \\
\hline S16 & - & - & - & - & - & - & - & - & - & - & - & - \\
\hline S17 & - & - & - & - & - & - & - & - & - & - & - & - \\
\hline S18 & - & - & - & - & - & - & - & - & - & - & - & - \\
\hline S19 & - & - & - & - & - & - & - & - & - & - & - & - \\
\hline S20 & - & - & - & - & - & - & - & - & - & - & - & - \\
\hline S21 & - & - & - & - & - & - & - & - & - & - & - & - \\
\hline S22 & - & - & - & - & - & - & - & - & - & - & - & - \\
\hline S23 & - & - & - & - & - & - & - & - & - & - & - & - \\
\hline S24 & - & - & - & - & - & - & - & - & - & - & - & - \\
\hline S25 & - & - & - & - & - & - & - & - & - & - & - & - \\
\hline S26 & - & - & - & - & - & - & - & - & - & - & - & - \\
\hline
\end{tabular}




\begin{tabular}{|c|c|c|c|c|c|c|c|c|c|c|c|c|}
\hline \multirow[b]{2}{*}{ Isolates } & \multicolumn{12}{|c|}{ Crude oil $\mu \mathrm{l}$} \\
\hline & 100 & 50 & 25 & 12.5 & 6.25 & 3.12 & 1.56 & 0.78 & 0.39 & 0.19 & 0.09 & 0 \\
\hline S27 & - & - & - & - & - & - & - & - & - & - & - & - \\
\hline $\mathrm{S} 28$ & - & - & - & - & - & - & - & - & - & - & - & - \\
\hline $\mathrm{S} 29$ & - & - & - & - & - & - & - & - & - & - & - & - \\
\hline S30 & - & - & - & - & - & - & - & - & - & - & - & - \\
\hline S31 & - & - & - & - & - & - & - & - & - & - & - & - \\
\hline $\mathrm{S} 32$ & - & - & - & - & - & - & - & - & - & - & - & - \\
\hline S33 & - & - & - & - & - & - & - & - & - & - & - & - \\
\hline S34 & - & - & - & - & - & - & - & - & - & - & - & - \\
\hline S35 & - & - & - & - & - & - & - & - & - & - & - & - \\
\hline S36 & - & - & - & - & - & - & - & - & - & - & - & - \\
\hline S37 & - & + & + & + & + & + & + & + & + & + & + & + \\
\hline S38 & - & + & + & + & + & + & + & + & + & + & + & + \\
\hline S39 & - & + & + & + & + & + & + & + & + & + & + & + \\
\hline $\mathrm{S} 40$ & - & + & + & + & + & + & + & + & + & + & + & + \\
\hline $\mathrm{S} 42$ & - & + & + & + & + & + & + & + & + & + & + & + \\
\hline $\mathbf{S} 43$ & - & + & + & + & + & + & + & + & + & + & + & + \\
\hline $\mathrm{S} 44$ & - & + & + & + & + & + & + & + & + & + & + & + \\
\hline $\mathrm{S} 45$ & - & + & + & + & + & + & + & + & + & + & + & + \\
\hline $\mathrm{S} 46$ & - & + & + & + & + & + & + & + & + & + & + & + \\
\hline $\mathrm{S} 47$ & - & - & + & + & + & + & + & + & + & + & + & + \\
\hline $\mathrm{S} 48$ & - & + & + & + & + & + & + & + & + & + & + & + \\
\hline $\mathrm{S} 49$ & - & + & + & + & + & + & + & + & + & + & + & + \\
\hline S50 & - & + & + & + & + & + & + & + & + & + & + & + \\
\hline S51 & + & + & + & + & + & + & + & + & + & + & + & + \\
\hline S52 & - & + & + & + & + & + & + & + & + & + & + & + \\
\hline S53 & - & + & + & + & + & + & + & + & + & + & + & + \\
\hline S54 & - & + & + & + & + & + & + & + & + & + & + & + \\
\hline S55 & + & + & + & + & + & + & + & + & + & + & + & + \\
\hline S56 & - & + & + & + & + & + & + & + & + & + & + & + \\
\hline S57 & - & + & + & + & + & + & + & + & + & + & + & + \\
\hline S58 & - & + & + & + & + & + & + & + & + & + & + & + \\
\hline S59 & - & + & + & + & + & + & + & + & + & + & + & + \\
\hline S60 & - & + & + & + & + & + & + & + & + & + & + & + \\
\hline S61 & - & + & + & + & + & + & + & + & + & + & + & + \\
\hline S62 & - & + & + & + & + & + & + & + & + & + & + & + \\
\hline S63 & - & + & + & + & + & + & + & + & + & + & + & + \\
\hline S64 & - & + & + & + & + & + & + & + & + & + & + & + \\
\hline S65 & - & + & + & + & + & + & + & + & + & + & + & + \\
\hline S66 & - & + & + & + & + & + & + & + & + & + & + & + \\
\hline S67 & - & + & + & + & + & + & + & + & + & + & + & + \\
\hline S68 & - & + & + & + & + & + & + & + & + & + & + & + \\
\hline S69 & - & + & + & + & + & + & + & + & + & + & + & + \\
\hline S70 & + & + & + & + & + & + & + & + & + & + & + & + \\
\hline S71 & - & + & + & + & + & + & + & + & + & + & + & + \\
\hline S72 & - & + & + & + & + & + & + & + & + & + & + & + \\
\hline S73 & - & + & + & + & + & + & + & + & + & + & + & + \\
\hline S74 & + & + & + & + & + & + & + & + & + & + & + & + \\
\hline S75 & + & + & + & + & + & + & + & + & + & + & + & + \\
\hline S76 & - & + & + & + & + & + & + & + & + & + & + & + \\
\hline S77 & - & + & + & + & + & + & + & + & + & + & + & + \\
\hline S78 & - & + & + & + & + & + & + & + & + & + & + & + \\
\hline S79 & - & + & + & + & + & + & + & + & + & + & + & \\
\hline
\end{tabular}




\begin{tabular}{|c|c|c|c|c|c|c|c|c|c|c|c|c|}
\hline \multirow[b]{2}{*}{ Isolates } & \multicolumn{12}{|c|}{ Crude oil $\mu \mathrm{l}$} \\
\hline & 100 & 50 & 25 & 12.5 & 6.25 & 3.12 & 1.56 & 0.78 & 0.39 & 0.19 & 0.09 & 0 \\
\hline S80 & - & + & + & + & + & + & + & + & + & + & + & + \\
\hline S81 & - & + & + & + & + & + & + & + & + & + & + & + \\
\hline S82 & - & + & + & + & + & + & + & + & + & + & + & + \\
\hline S83 & - & + & + & + & + & + & + & + & + & + & + & + \\
\hline S84 & - & + & + & + & + & + & + & + & + & + & + & + \\
\hline S85 & - & + & + & + & + & + & + & + & + & + & + & + \\
\hline
\end{tabular}

(+) Bacterial growth was observed (-) Bacterial growth was not observed

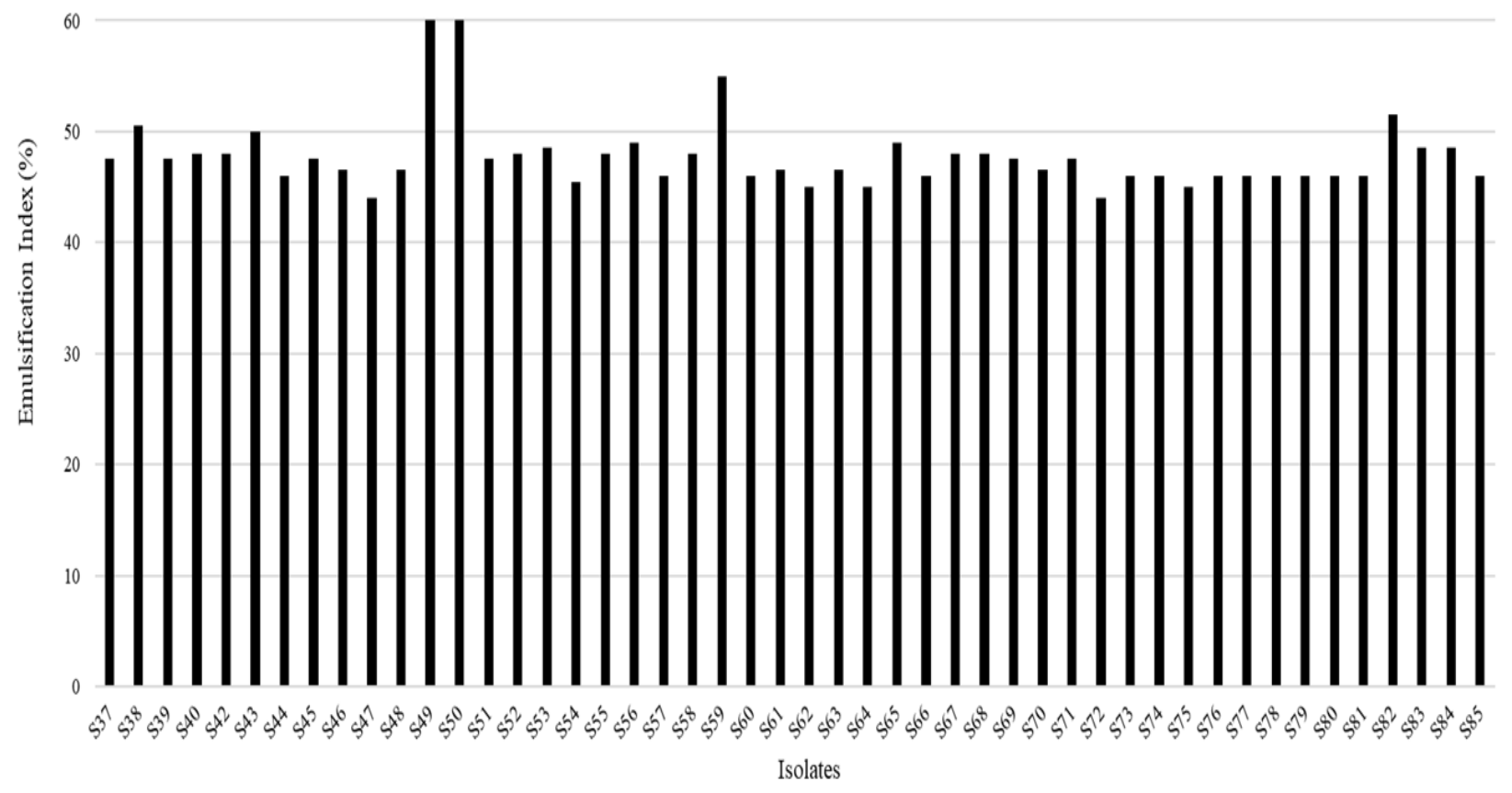

Figure 2. The percentage of emulsification index (E24) of the bacterial isolates that was able to use crude oil

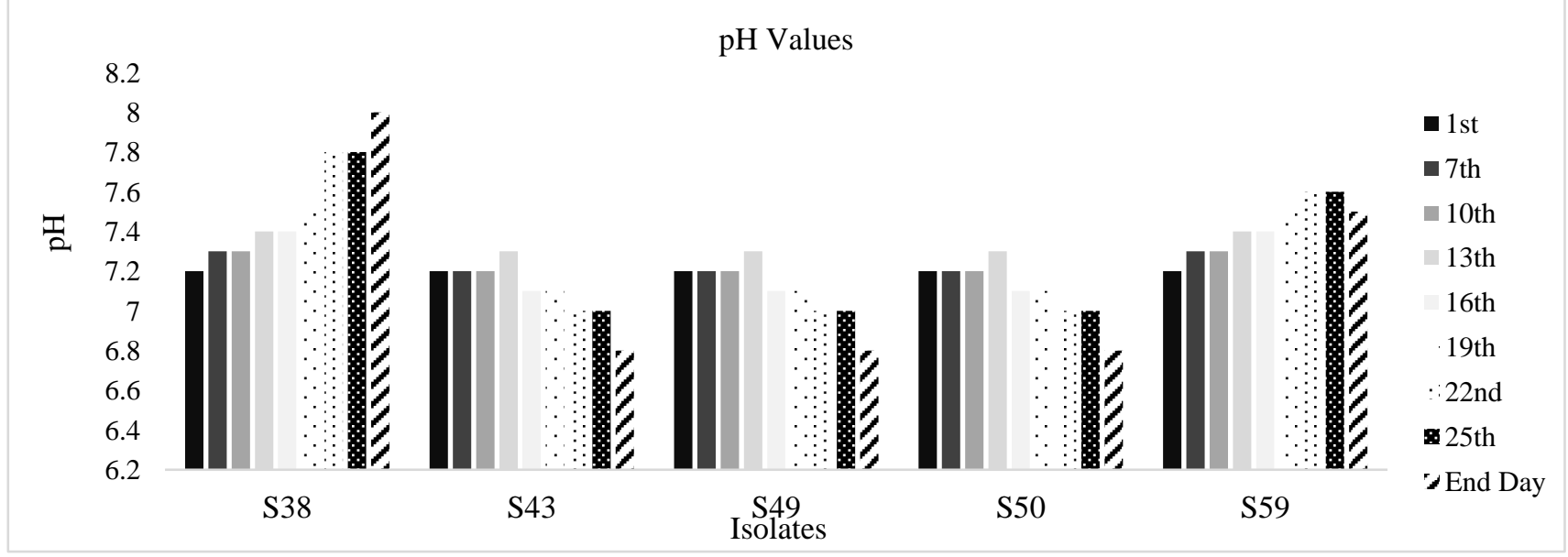

Figure 3. Recorded $\mathrm{pH}$ values in the flask containing crude oil and bacteria. 


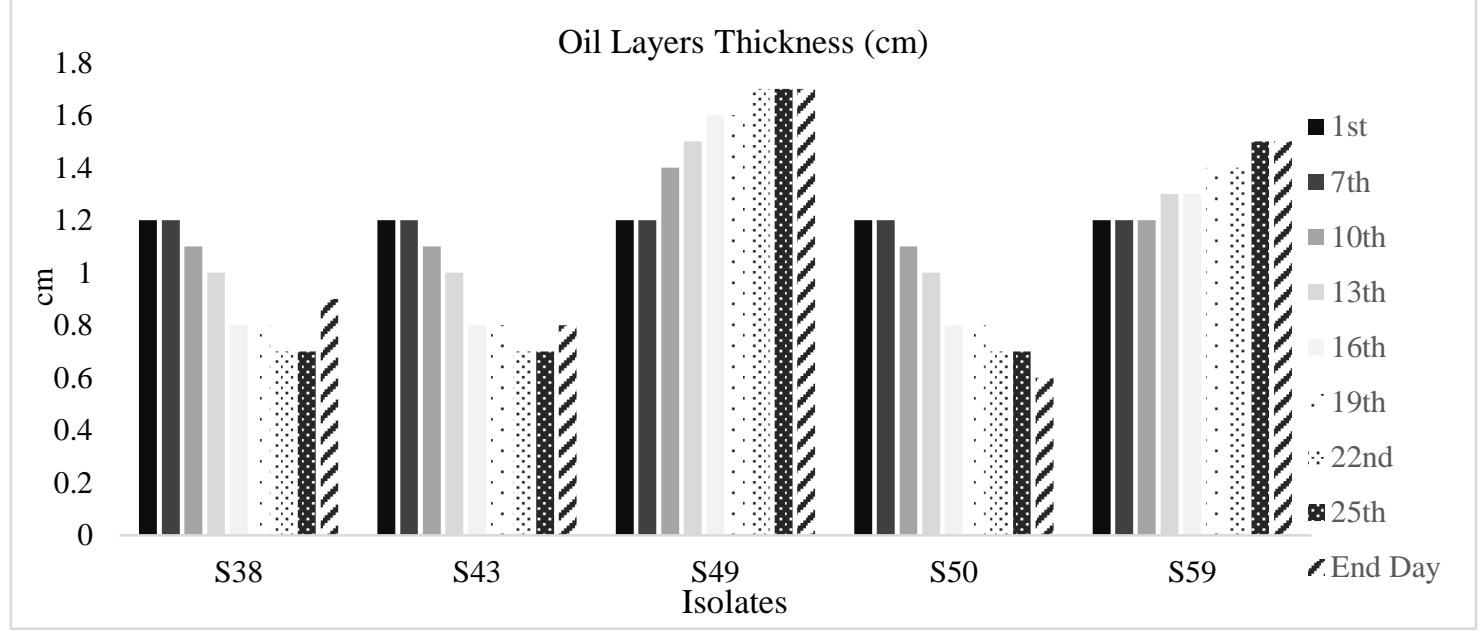

Figure 4. Oil layer thickness $(\mathrm{cm})$ obtained from individual bacterial isolates

Table 4. Recorded $\mathrm{pH}$ values and oil layers thickness $(\mathrm{cm})$ in the flask containing crude oil and bacterial isolates

\begin{tabular}{|c|c|c|c|c|c|c|c|c|c|}
\hline \multirow{3}{*}{ Isolates } & \multicolumn{9}{|c|}{$\mathrm{pH}$ Values } \\
\hline & \multicolumn{9}{|l|}{ Days } \\
\hline & $1 \mathrm{st}$ & 7th & 10 th & 13th & 16 th & 19 th & $22 \mathrm{nd}$ & 25 th & 30th \\
\hline S38 & $7.2 \pm 0.01$ & $7.3 \pm 0.01$ & $7.3 \pm 0.02$ & $7.4 \pm 0.06$ & $7.4 \pm 0.06$ & $7.5 \pm 0.08$ & $7.8 \pm 0.15$ & $7.8 \pm 0.15$ & $8 \pm 0,21$ \\
\hline $\mathrm{S} 43$ & $7.2 \pm 0.01$ & $7.2 \pm 0.01$ & $7.2 \pm 0.02$ & $7.3 \pm 0.06$ & $7.1 \pm 0.06$ & $7.1 \pm 0.08$ & $7.0 \pm 0.15$ & $7 \pm 0.15$ & $6,8 \pm 0,21$ \\
\hline $\mathrm{S} 49$ & $7.2 \pm 0.01$ & $7.2 \pm 0.01$ & $7.2 \pm 0.02$ & $7.3 \pm 0.06$ & $7.1 \pm 0.06$ & $7.1 \pm 0.08$ & $7.0 \pm 0.15$ & $7 \pm 0.15$ & $6,9 \pm 0,21$ \\
\hline S50 & $7.2 \pm 0.01$ & $7.2 \pm 0.01$ & $7.2 \pm 0.02$ & $7.3 \pm 0.06$ & $7.1 \pm 0.06$ & $7.1 \pm 0.08$ & $7.0 \pm 0.15$ & $7 \pm 0.15$ & $6,8 \pm 0,21$ \\
\hline S59 & $7.2 \pm 0.01$ & $7.3 \pm 0.01$ & $7.3 \pm 0.02$ & $7.4 \pm 0.06$ & $7.4 \pm 0.06$ & $7.5 \pm 0.08$ & $7.6 \pm 0.15$ & $7,6 \pm 0.15$ & $7.5 \pm 0,21$ \\
\hline \multirow{3}{*}{ Isolates } & \multicolumn{9}{|c|}{ Oil Layers Thickness $(\mathrm{cm})$} \\
\hline & \multicolumn{9}{|l|}{ Days } \\
\hline & $1 \mathrm{st}$ & 7 th & 10 th & 13th & 16 th & 19 th & 22nd & 25 th & $\begin{array}{l}\text { End } \\
\text { Day }\end{array}$ \\
\hline S38 & $1.2 \pm 0.01$ & $1.2 \pm 0.01$ & $1.1 \pm 0.05$ & $1.0 \pm 0.09$ & $0.8 \pm 0.14$ & $0.8 \pm 0.15$ & $0.7 \pm 0.19$ & $0.7 \pm 0.19$ & $0.9 \pm 0.19$ \\
\hline $\mathrm{S} 43$ & $1.2 \pm 0.01$ & $1.2 \pm 0.01$ & $1.1 \pm 0.05$ & $1.0 \pm 0.09$ & $0.8 \pm 0.14$ & $0.8 \pm 0.15$ & $0.7 \pm 0.19$ & $0.7 \pm 0.19$ & $0.8 \pm 0.19$ \\
\hline S49 & $1.2 \pm 0.01$ & $1.2 \pm 0.01$ & $1.4 \pm 0.05$ & $1.5 \pm 0.09$ & $1.6 \pm 0.14$ & $1.6 \pm 0.15$ & $1.7 \pm 0.19$ & $1.7 \pm 0.19$ & $1.7 \pm 0.19$ \\
\hline S50 & $1.2 \pm 0.01$ & $1.2 \pm 0.01$ & $1.1 \pm 0.05$ & $1.0 \pm 0.09$ & $0.8 \pm 0.14$ & $0.8 \pm 0.15$ & $0.7 \pm 0.19$ & $0.7 \pm 0.19$ & $0.6 \pm 0.19$ \\
\hline S59 & $1.2 \pm 0.01$ & $1.2 \pm 0.01$ & $1.2 \pm 0.05$ & $1.3 \pm 0.09$ & $1.3 \pm 0.14$ & $1.4 \pm 0.15$ & $1.4 \pm 0.19$ & $1.5 \pm 0.19$ & $1.5 \pm 0.19$ \\
\hline
\end{tabular}

Data are means $(\mathrm{n}=5) \pm \mathrm{SD}$

The thickness of oil layers was recorded lower $(0.7 \mathrm{~cm})$ in the medium of $\mathrm{S} 59-E$. coli1 as compared to the reference medium $(1.2 \mathrm{~cm})$ without any bacterial strains. This situation implied that oil degradation rate affected by $\$ 59-E$. coli1 during the incubation period.

Throughout the 30-day incubation period, recorded maximum and minimum $\mathrm{pH}$ values were 8 and 6.8 , respectively.

Oil pollution is an environmental problem of increasing importance. Hydrocarbon-degrading microorganisms, adapted to grow and thrive in oilcontaining environments, have an important role in the biological treatment of this pollution. The biodegradation of many components of petroleum hydrocarbons by bacteria has been reported in a variety of terrestrial and marine ecosystems (Atlas,
1995; Pritchard and Costa, 1991; Ron and Rosenberg, 2002; Ciftci and Altug, 2010; Altug et al., 2011; Altug et al., 2012).

The degradation of complex molecules in the nature can be accelerated by human activities with biological and environmental changes. Since each bacteria shows higher productivity in its own adaptive ecosystem, identification of bacterial community based on each geographical areas are important for understanding of bacterial remediation occurrence potential of the regions.

In this study Sapanca Lake was selected as a study area due to being an important water source and was surrounded by motorways (TEM, Trans-European Motorways) and a railway connecting Asia to Europe (Tanık et al., 1998). Locating of NATO pipeline at the 
south of this lake also made this area even better study site.

Since, Sapanca Lake is under the potential threat of oil pollution, to identify of the local bacteria as a possible bioremediation agent is important. Correspondingly, in the MIC test it was detected that the first thirty-six strains were displayed negative results against crude oil in 2008. However, 37th strain and followers were found to be resistant to crude oil after May of 2009. These results were associated with the unexpected oil spillage happened in the Sapanca Lake at that time. This situation showed that the bacteria did not meet with the petroleum-derived contaminants during this period. NATO oil pipeline leaked in May 2009 and then positive results have been received in MIC tests which were carried out after on this date. As a result, the bacteria isolated from Sapanca Lake displayed different metabolically behaviors with respect to crude oil resistance after the unexpected accident of the region.

It has been well documented that various crude oil tolerant microorganisms including bacteria (Serratia marcescens, Pseudomonas aeruginosa, Enterobacter aerogenes and Escherichia coli etc.) yeast and fungi were isolated from natural environments such as soil, marine and fresh water (Yakimov et al., 2007; Zarate et al 2014). They tolerate high concentrations of the hydrocarbons and have a high capability for their degradation. Most of which belong to Gammaproteobacteria (Okoh and Trejo-Hernandez, 2006; Jacques et al., 2008; Onbasili et al., 2011). In this study, while S59-E. coli and $A$. hydrophila gave the best results, the bacteria species displayed high performance against crude oil were detected to be $\mathrm{S} 49-$ $A$. hydrophila, S50- $A$. hydrophila, S59- E. coli1, S38- $A$. hydrophila and S43-E. cloaceae.

It was reported that $\mathrm{pH}$ values affect the emulsion capacity and stable activity of rhamnolipid-type biosurfactants' (Prieto et al., 2008). The decreases in $\mathrm{pH}$ values observed during incubation period was positively associated with degradation rate and this situation reported as an indicator to utilization of crude oil by microbes as an energy source in media (Anon 1991; Udo and Fayemi, 1995; Head et al., 2006). Similarly, in this study observed decreases in $\mathrm{pH}$ values were associated with positive efficiency of bacteria on degradation of crude oil. During the study the $\mathrm{pH}$ varied between 6 and 8 values (Table 4). The initial $\mathrm{pH}$ values were adjusted to 7.2 in in experimental setups. The most extreme drop in $\mathrm{pH}$ to a value 6.8 was observed the $30^{\text {th }}$ day in $\mathrm{S} 43-E$. cloacea and $550-E$. coli. A decrease of 6.8 in the $\mathrm{pH}$ values was observed especially in the case of thinning in the petroleum layer. This situation implies that utilization of crude oil as an energy source by S43-E. cloacea and S50-E. coli was higher than the others isolates.
Principally, the decrease of oil layer thickness during incubation period was also positively associated with degradation rate. In this study, oil layer thickness in the experimental set up, containing different bacterial media, displayed variables throughout the incubation period.

Despite of the observed decreases in oil layer thickness in the experimental set up, some increases was also recorded. For instance, the highest thickness of the oil layer was recorded in S49- and S59 strains. According to Altuğ et al. (2011) and Dean et al. (2001) many hydrocarbon degrading bacteria produced bio surfactants that assist in hydrocarbon association with the substrate. In this study, it can be assumed that the increasing of the oil layer thickness in the media containing S49- and S59 strains is due to production of the biosurfactants by bacteria. In this study $\mathrm{E}_{24}$ values recorded also showed that these isolates have emulsification potential for produce biosurfactants.

Biosurfactants can promote the growth of oildegrading bacteria and improve their capacity to utilize hydrocarbons as carbon source. Some bacteria, remarkably, produce waxes after degrading crude oil (Ishige et al., 2003). Emulsification $\left(\mathrm{E}_{24}\right)$ value was accepted as an indicator to determinate the candidate bacterial species which was resistant to crude oil. Due to bioemulsifiers apply to stimulate the bioremediation process in fields as a stabilizer, to understand $\mathrm{E}_{24}$ value of the candidate bacteria is important for bioremediation studies. In this study, $\mathrm{E}_{24}$ values of the isolates were between $60 \%$ and $44.06 \%$. The results showed that the bacterial strains tested in this study may be considered as bioemulsifier-overproducing bacteria for possible use in bioremediation studies to increase the solubility and bioavailability of hydrocarbons in natural environments.

It is not surprising that hydrocarbons are considered to be contaminants distributed in large areas in nature. The abilities of bacteria in bioremediation arena is being studied extensively because bacterial isolates are easily cultivatable, better suited to molecular biology techniques. Also, they metabolize chlorinated organic substances, mineralize such chemical substances, and use carbon as a source of energy (Bouwer ve Zehnder, 1993).

Altuğ et al. (2011, 2012) reported that bacterial strains isolated from the northern Marmara Sea and Istanbul Strait (Turkey) sustained high MIC values. In this study, though, the bacteria isolated from Sapanca Lake displayed lower MIC values than those of Marmara Sea. Both results offer opportunities for further possible remediation studies.

\section{CONCLUSION}

The use of domestic bacteria in the removal of petroleum hydrocarbons from the environment is 
extremely important in terms of end-point acceleration and recommended method. In this study oil degrading bacteria in Sapanca Lake were investigated for the first time.

The strain of S59-E. coli1 showed the highest degradation ability among five selected strains and it determined as potential candidates for detailed studies. We suggest that natural bacterial isolates from oil polluted areas are more suitable candidates as oil-degrading bacterial strains for the rehabilitation of oil polluted aquatic ecosystems.

\section{ACKNOWLEDGEMENTS}

The authors would like to thank the Scientific and Technological Research Council of Turkey (TUBITAK) as a financial supporter of the study. Project number: $107 \mathrm{G} 261$.

\section{REFERENCES}

Akçaalan R, Köker L, Gürevin C, Albay M 2014. Planktothrix rubescens: A perennial presence and toxicity in Lake Sapanca. Turkish Journal of Botany, 38: 782-789.

APHA 2000. Standard Methods for the Examination of Water and Wastewater $20^{\text {th }}$ Edition. Clesceri, L.S., A.E Greenberg and A.D Eaton (eds). American Public Health Association, American Water Works Association and Water Environment Federation. Washington, D.C.

ANON 1997. National Committee for Clinical Laboratory Standards. Methods for dilution antimicrobial susceptibility tests for bacteria that grow aerobically. $4^{\text {th }}$ ed. Publication M7-A2, Villanova, PA: National Committee for Clinical Laboratory Standards.

ANON 1991. U. S. Congress, Office of Technology Assesment, Bioemediation for Marine Oil Spills, OTA-BP-O-70 Washington, DC: U. S. Government Printing Office.

ANON 1998. Su Kalitesi Kontrolü, İzlenmesi ve Özel Çalışmalar: Sapanca Gölü ve Drenaj Alanı, DSI (General Directorate of State Hydraulic Works). 228-300, Ankara (In Turkish).

ANON 1984. Sapanca Gölü Kirlilik Çalışması (The Pollution Study of Sapanca Lake). DSI (General Directorate of State Hydraulic Works). Technical Report 135, Ankara (In Turkish).

Akkoyunlu A, Akiner M 2012. Pollution evaluation in streams using water quality indices: A case study from Turkey's Sapanca Lake Basin. Ecological Indicator, 18: 501-511.

Altug G, Gürün S, Yüksel B, Memon A 2011. The Investigation of Oil Degrading Capacity of Bacterial Strains Isolated from Different Environments in Turkey, Fresenius Environmental Bulletin, 20, 886-893.
Altug G, Gürün S, Yüksel B, Memon A 2012. Oil Hydrocarbon Degradation Effects of Some Bacteria Isolated from Various Environments in Turkey. First National Workshop on Marine Biotechnology and Genomics. 24-25 May 2012, Muğla-Turkey, pp. 10-25.

Atlas RM 1995. Petroleum Biodegradation and Oil Spill Bioremediation. Marine Pollution Bulletin, 31(4-12): 178-182.

Bouwer EJ, Zehnder AJB 1993. Bioremediation of organic compounds - putting microbial metabolism to work, Trends in Biotechnology, 11, 360-367.

Ciftci PS, Altug G 2010. Study on the Degradation Ability of the Bacteria Isolated from the sea of Marmara in Oil Hydrocarbons, Turkey. 39th CIESM (Commission Internationale pour l'Exploration Scientifique de la mer Mediterranee) CongressRapp. Comm In. Mer Medit, 39, VeniceItaly. pp:346.

Cole JJ, Findlay S, Pace M L 1988. Bacterial production in fresh and saltwater ecosystems-a cross-system overview. Marine Ecology Progress Series, 43: 1-10.

Cotner JB, Biddanda BA 2002. Small players, large role: microbial influence on biogeochemical processes in pelagic aquatic ecosystems. Ecosystems, 5:105-121.

Das N, Chandran P 2011. Microbial Degradation of Petroleum Hydrocarbon Contaminants: An Overview. SAGE-Hindawi Access to Research Biotechnology Research International. Volume 2011, Article ID 941810, 13 pages. doi:10.4061/2011/941810.

Dean SM, Jin Y, Cha DK, Wilson SV, Radosevich M 2001. Phenanthrene Degradation in Soils $\mathrm{Co}^{-}$ Inoculated with Phenanthrene-Degrading and Biosurfactant-Producing Bacteria. Journal of Environmental Quality, 30: 1126-1133.

DeBruyn JM, Chewning CS, Sayler GS 2007. Comparative quantitative prevalence of Mycobacteria and functionally abundant nidA, nahAc, and nagAc dioxygenase genes in coal tar contaminated sediments. Environmental Science \& Technology, 41: 5426-5432. doi: 10.1021/es070406c

Duman F, Aksoy A, Demirezen D 2007a. Seasonal Variability of Heavy Metals in Surface Sediment of Lake Sapanca, Turkey. Environmental Monitoring and Assessment, 133:277-283.

Duman F, Sezen G, Tug GN 2007b. Seasonal Changes of Some Heavy Metal Concentrations in Sapanca Lake Water, Turkey. International Journal of Natural \& Engineering Sciences. 1(3): 25-28.

Ezikpe MNI, Gbenle OG, Ilori MO, Okpuzor J, Osuntoki AA 2009. Evaluation of Alcaligenes faecalis degradation of chrysene and diesel oil with concomitant production of biosurfactant. Research Journal of Environmental Toxicology,3: 159-169. 
Farrington JW 1980. An overview of the biogeochemistry of fossil fuel hydrocarbons in the marine environment. Advances in Chemistry, 185: $1-22$.

Head I, Jones D, Rolling W 2006. Marine Organisms make a meal of oil. Nature Reviews Microbiology, 4: 173-182.

Holmes B., Willcox WR, Lapage SP 1978. Identification of Enterobacteriaceae by the API 20E system. Journal of Clinical Pathology, 31(1): 22-30.

Ishige T, Tani A, Sakai Y, Kato N 2003. Wax ester production by bacteria. Current Opinion in Microbiology, 6(3): 244-250.

Jacques RJS, Okeke BC, Bento FM, Teixeira AS, Peralba MCR, Camargo FAO 2008. Microbial consortium bioaugmentation of a polycyclic aromatic hydrocarbons contaminated soil. Bioresource Technology, 99(7): 2637-2643.

Le-Petit J, Barthelemy MH 1968. The hydrocarbons in water: the problem of microorganisms using the littoral zones. Annales De l'Institut Pasteur, 144: 149-158.

Marchand C, St-Arnaud M, Hogland W, Bell TH, Hijri M 2017. Petroleum biodegradation capacity of bacteria and fungi isolated from petroleumcontaminated soil. International Biodeterioration \& Biodegradation, 116: 48-57.

Morkoç E 2008. Water Quality Properties of Sapanca Lake. Ed. H. Okgerman, G. ALTUĞ. Scientific Overview of Sapanca Lake. Turkish Marine Research Foundation. No: 28. P: 140-148 (In Turkish).

Newton RJ, Jones SE, Eiler A, McMahon KD, Bertilsson S 2011. A guide to the natural history of freshwater lake bacteria. Microbiology and Molecular Biology Reviews, 75(1): 14-49 DOI: 10.1128/MMBR.00028-10.

Okoh AI, Trejo-Hernandez MR 2006. Remediation of petroleum hydrocarbon polluted systems: Exploiting the bioremediation strategies. African Journal of Biotechnology, 5(25): 2520-2525.

Onbasili D, Aslim B, Yuvali Celik G 2011. Investigation of metabolite productions and degradation of hazardous organic pollutants by
Pseudomonas spp. Journal of Applied Biological Sciences, 5(2): 9-14.

Prieto LM, Michelon M, Burkert JFM, Kalil SJ, Burker CAV 2008. The production of rhamnolipid by a Pseudomonas aeruginosa strain isolated from a southern coastal zone in Brazil. Chemosphere, 71(9): 1781-1785.

Pritchard HP, Costa CF 1991. EPA's Alaska oil spill bioremediation project. Environmental Science \& Technology, 25(3): 372-379.

Rahman KSM, Rahman JT, Lakshmanaperumalsamy P, Banat IM 2002. Towards efficient crude oil degredation by a mixed bacterial consortium, Bioresource Technology, 85: 257-261.

Ron EZ, Rosenberg E 2002. Biosurfactants and oil bioremediation. Environmental Biotechnology, 13(3): 249-252.

Sarubbo LA 2006. Production and stability studies of the bioemulsifier obtained from a strain of Candida glabrata UCO1002. Journal of Biotechnology, 9: 400-406.

Tabatabaee A, Assadi MM, Noohi AA, Sajadian VA 2005. Isolation of biosurfactant producing bacteria from oil reservoirs, Iranian Journal of Environmental Health Science \& Engineering, 2: 612.

Tanik A, Beler Baykal B, Gönenc E, Meric S, Öktem Y 1998. Effect and Control of Pollution in Catchment Area of Lake Sapanca, Turkey. Environmental Management, 22(3): 407-414.

Udo EJ, Fayemi AAA 1995. The effect of oil pollution on soil germination, growth and nutrient uptake of corn. Journal of Environmental Quality, 4: 537-540.

Yakimov MM, Timmis KN, Golyshin PN 2007. Obligate oil-degrading marine bacteria. Current Opinion in Biotechnology, 18:257-266.

Zarate MGM, González JFC, Pérez ASR, Domínguez EE, Oviedo JT, Juárez VMM, Rodríguez IA 2014. Isolation and Identification of Bacteria and Fungi Resistant to Crude Oil. Journal of Multidisciplinary Engineering Science and Technology, 3(7): 52735278 . 